\title{
Review
}

\section{Adult-onset Mendelian PEO Associated with Mitochondrial Disease}

\author{
Ewen W. Sommerville ${ }^{\mathrm{a}}$, Patrick F. Chinnery ${ }^{\mathrm{b}}$, Gráinne S. Gorman ${ }^{\mathrm{a}, *}$ and Robert W. Taylor ${ }^{\mathrm{a}}$ \\ ${ }^{a}$ Wellcome Trust Centre for Mitochondrial Research, Institute of Neuroscience, Newcastle University, \\ Newcastle upon Tyne, UK \\ ${ }^{\mathrm{b}}$ Wellcome Trust Centre for Mitochondrial Research, Institute of Genetic Medicine, \\ Newcastle University, Newcastle upon Tyne, UK
}

\begin{abstract}
.
Background: Progressive external ophthalmoplegia (PEO) is an eye movement disorder characterised by paresis of the extra ocular muscles and muscle restricted multiple mitochondrial DNA (mtDNA) deletions. Classification of patients is particularly difficult due to overlapping phenotypes and a poor genotype-phenotype relationship. Despite the identification of several nuclear encoded genes causing PEO, over half of patients with clinically confirmed PEO do not have a genetic diagnosis.

Objective: To systematically review genotypic and phenotypic correlates of published cases of adult-onset PEO.

Methods: Patients were identified from interrogation of articles from Scopus, Medline via PubMed, and Genetic Abstracts databases using electronic searches (1st January 1970 to 8th November 2013). Reference lists and UniProt entries were also manually checked for additional articles.

Results: Twelve nuclear encoded genes were identified (TYMP, SLC25A4, POLG, C10ORF2, OPA1, POLG2, RRM2B, TK2, $D G U O K, M P V 17, M G M E 1$, and $D N A 2$ ) systematically from 583 patients. At the time of writing, mutations in $S P G 7$ and $A F G 3 L 2$ genes were reported to be associated with ophthalmoparesis and multiple mtDNA deletions in fourteen additional adult-onset PEO patients, bringing the total number of known genes to fourteen.

Conclusions: Diagnostic yield is still critically dependent on the meticulous clinical and biochemical characterisation of patients. Understanding the intimate relationship between genotype and phenotype remains a fundamental challenge. The results of this systematic review provide guidance to both patients and clinician about future prognosis, and will serve, in future, to assess methods of disease prevention and evaluation of targeted therapeutic strategies.
\end{abstract}

Keywords: Mitochondria, ophthalmoplegia, genotype, phenotype

\section{INTRODUCTION}

Progressive external ophthalmoplegia (PEO) is a disorder biochemically delineated by skeletal muscle restricted multiple mtDNA deletions [1]. PEO can occur from single-point mutation or large-scale dele-

\footnotetext{
*Correspondence to: Dr. Gráinne S Gorman, Wellcome Trust Centre for Mitochondrial Research, Institute of Neuroscience, The Medical School, Newcastle University, Framlington Place, Newcastle upon Tyne, NE2 4HH, UK. Tel.: +44 191 2827140; Fax: +44 191 2824373; E-mail: grainne.gorman@ncl.ac.uk.
}

tions of the mitochondrial (mt) DNA [2]. Defects of several nuclear encoded genes encoding mitochondrial proteins are also known to cause mtDNA instability leading to $\mathrm{PEO}$, including $P O L G$, encoding the only known mitochondrial DNA polymerase [3], twinkle protein encoded by C10ORF2 [4], and protein p53R2 encoded by $R R M 2 B$ [5]. Clinically, PEO is characterised by progressive paralysis of the extra ocular muscles (Fig. 1). Ptosis (drooping of the eyelids) and proximal myopathies are particularly common in PEO patients. However, additional symptoms can also 

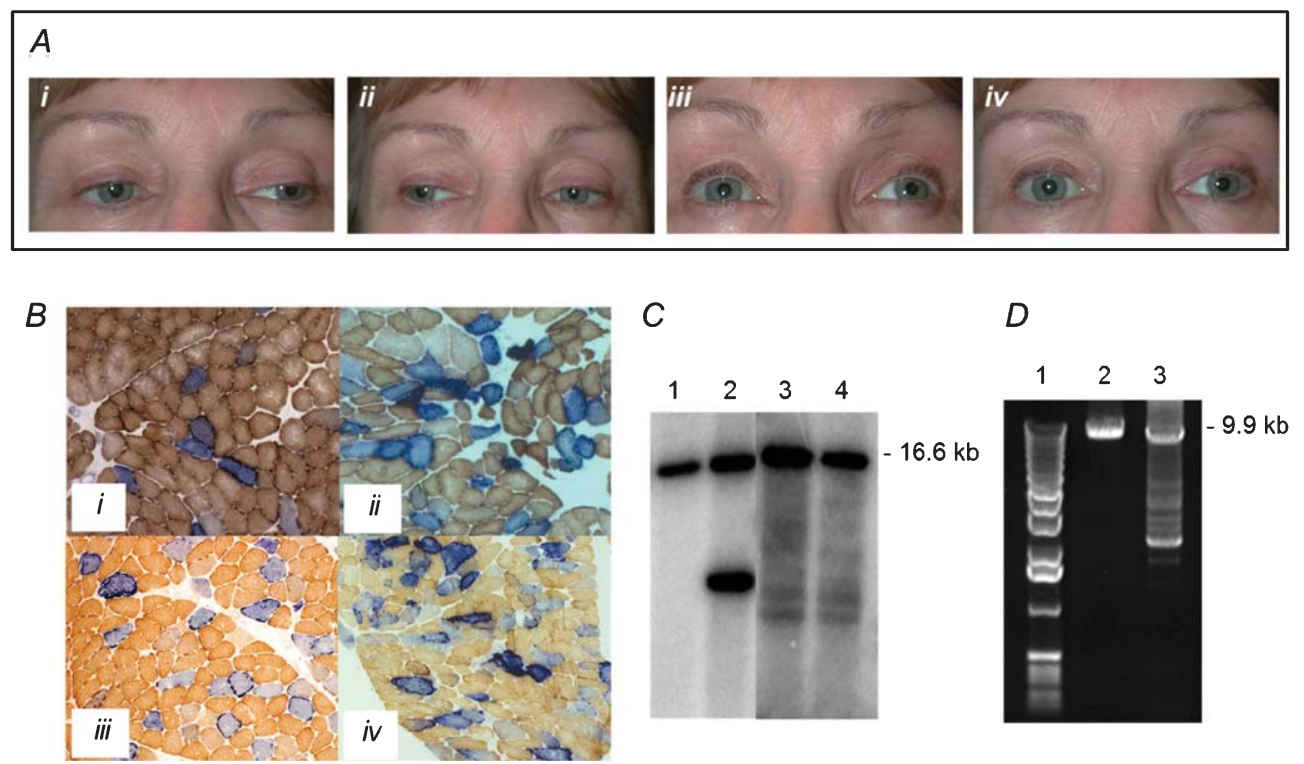

Fig. 1. The clinical, histochemical and mtDNA abnormalities associated with adult-onset Mendelian PEO and mitochondrial disease. A, Typical clinical features of a patient with mitochondrial PEO; extraocular motility in cardinal directions of gaze is reduced with unusually marked restriction of downgaze as the patient is asked to look left (i), right (ii), up, (iii) and down (iv). $B$, Sequential COX-SDH histochemisty of representative diagnostic muscle biopsies showing the presence of scattered COX-deficient fibres in patients with various disorders of adult-onset mtDNA maintenance abnormalities including ( ) recessive (homozygous p.(Ala467Thr)) POLG mutations; (ii) a dominant, heterozygous p.(Gln458His) C10ORF2 mutation; (iii) recessive (p.(Arg186Gly) and p.(Thr218Ile)) RRM2B mutations; (iv) recessive (p.(Asn288*) and p.(Lys558*)) SPG7 mutations; $(C)$ Southern blotting of muscle DNA showing a control (lane 1), a single, large-scale mtDNA deletion (lane 2) and the typical banding pattern observed with multiple mtDNA deletions (lanes 3 and 4 ); $(D)$ Long-range PCR also indicating the presence of multiple mtDNA deletions (lane 3) alongside a control (lane 2) and size markers (lane 1).

occur that include ataxia, psychiatric symptoms, sensory axonal neuropathies, and optic atrophy.

The manifestation of PEO resulting from a nuclear defect can be classified by the manner of inheritance, into autosomal dominant PEO (adPEO) and autosomal recessive PEO (arPEO). AdPEO is genetically and clinically heterogeneous with mutations of several nuclear encoded causative genes currently identified including POLG [3], C1OORF2 [4], and SLC25A4 [6]. In comparison, arPEO is not as well defined and tends to result in an early-onset presentation. In adult-PEO patients, recessive mutations of POLG [3], TYMP [7], TK2 [8], C10ORF2 [9], RRM2B [10], and DGUOK [11] have been described.

PEO is poorly characterised due to indigent genotype-phenotype correlates. Certain PEO patients may present similar phenotypes, but may show diverse genetic variation. Conversely, other patients may present vastly differing phenotypes, but show little genetic variation, often sharing mutations of the same gene. Furthermore, despite the identification of several nuclear encoded genes whereby mutations cause PEO; a genetic diagnosis remains to be made in a sizable number of patients with clinically confirmed PEO and a suspected nuclear defect.
To better understand the genotypic and phenotypic heterogeneity of adult-onset PEO with mtDNA instability, we reviewed all reported patients in the literature with adult-onset PEO.

\section{METHODS}

Selection Criteria and Search Strategy

The following inclusion criteria were determined:

- Adult patients (16 years or older) with PEO defined as paralysis or restricted movement of the extra ocular muscles and included patients described with 'ophthalmoplegia', 'ophthalmoparesis', or paralysis of the extra ocular muscles with or without additional clinical features;

- Exhibit biochemical evidence of mtDNA instability, either multiple mtDNA deletions, mtDNA depletion, or both;

- Have a confirmed genetic diagnosis.

Only electronic searches for English language articles, published between January 1st 1970 and November 8th 2013, were performed using three databases; Scopus, Medline via PubMed and Genetics 
Abstracts (Supplementary Tables 1-3). Duplicate articles were removed. Reference lists and the UniProt database were checked manually for additional articles (Supplementary Table 4). Patients described in multiple articles were included only once. Careful consideration as to whether patients from large, undefined cohorts could be included was taken. Key search terms employed included 'PEO', 'CPEO', 'ophthalmoplegia', 'ophthalmoparesis', 'adult', and 'adult-onset'.

\section{RESULTS}

Ophthalmoparesis related to mitochondrial disease retrieved from the electronic searches was described in 1129 articles. Of these, 160 papers described a total of 583 PEO patients who met inclusion criteria; harbouring mutations of twelve nuclear genes involved in mitochondrial maintenance and function (Fig. 2). Many patients described in the literature were not included in this review, due to symptoms presenting before 16 years old or the aetiology was not mitochondrial. At the time of writing, adult-onset PEO and mtDNA instability patients with mutations of $S P G 7$ and $A F G 3 L 2$ were additionally reported and there- fore there are 597 patients reported in 163 articles (Fig. 2). Thus, there are fourteen genes associated with adult-onset PEO and mtDNA instability (Table 1). All genes are known to localise to the mitochondria (Fig. 3). These are listed in order of discovery in adultonset PEO. The clinical, molecular, and genetic data for all genes have been summarised (Supplementary Tables 5-10).

\section{TYMP - thymidine phosphorylase}

TYMP encodes thymidine phosphorylase and catalyses the conversion of thymidine to thymine and deoxyuridine to uracil [12]. Depletion of thymidine phosphorylase leads to the accumulation of thymidine and deoxyuridine, disturbing dNTP supply and affecting mtDNA synthesis. Mutations cause mitochondrial neurogastrointestinal encephalopathy (MNGIE), a multisystem disorder where PEO is a common symptom. We identified 49 patients who met the review criteria. It is a recessive disorder with the majority of patients presenting with mtDNA depletion; relatively few have been reported to exhibit biochemical evidence of multiple mtDNA deletions [7, 13].

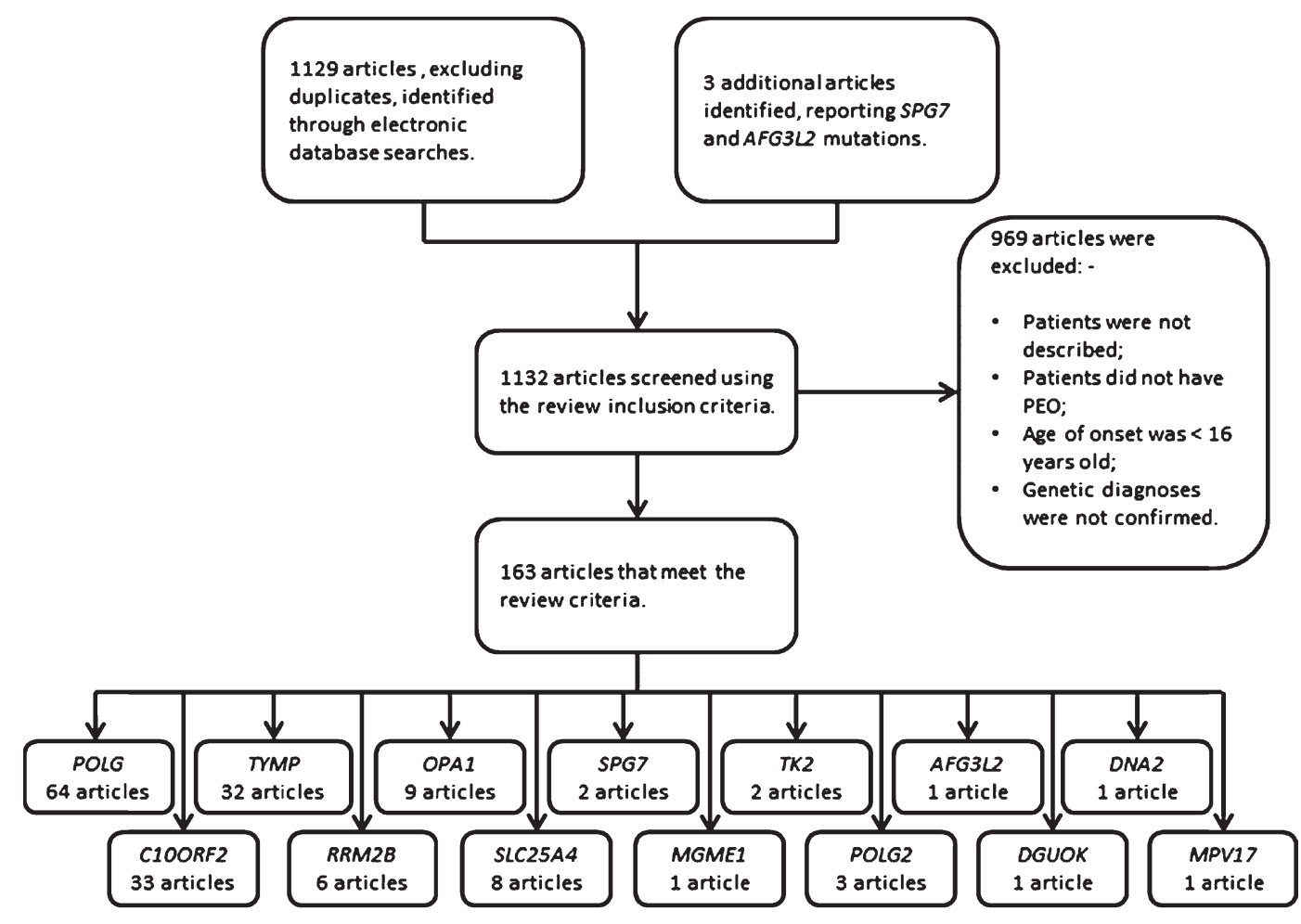

Fig. 2. The study of articles identified using electronic search terms. A study flow diagram summarising the filtering of articles identified by the electronic searches to include those describing only adult-onset PEO patients and the inclusion of three articles reporting patients with $S P G 7$ or AFG3L2 mutations, which were not identified systematically. 
Table 1

Summary of genes $(n=14)$ associated with adult-onset PEO and mtDNA instability

\begin{tabular}{|c|c|c|c|c|}
\hline Gene & Genotype & Effect on mtDNA & $\begin{array}{l}\text { Number of patients in } \\
\text { the literature that meet } \\
\text { the review criteria }{ }^{1}\end{array}$ & $\begin{array}{l}\text { Number of articles } \\
\text { describing patients }\end{array}$ \\
\hline$P O L G$ & $\begin{array}{l}\text { Dominant and } \\
\text { recessive }\end{array}$ & $\begin{array}{l}\text { Multiple deletions } \\
\text { and depletion }\end{array}$ & 258 & 64 \\
\hline C10ORF2 & $\begin{array}{l}\text { Dominant and } \\
\text { recessive }\end{array}$ & $\begin{array}{l}\text { Multiple deletions } \\
\text { and depletion }\end{array}$ & 143 & 33 \\
\hline TYMP & Recessive & $\begin{array}{l}\text { Multiple deletions } \\
\text { and depletion }\end{array}$ & 49 & 32 \\
\hline$R R M 2 B$ & $\begin{array}{l}\text { Dominant and } \\
\text { recessive }\end{array}$ & $\begin{array}{l}\text { Multiple deletions } \\
\text { and depletion }\end{array}$ & 42 & 6 \\
\hline OPAl & Dominant & Multiple deletions & 42 & 9 \\
\hline SLC25A4 & Dominant & Multiple deletions & 39 & 8 \\
\hline$S P G 7$ & $\begin{array}{l}\text { Dominant and } \\
\text { recessive }\end{array}$ & Multiple deletions & 12 & 2 \\
\hline MGME1 & Recessive & Multiple deletions & 3 & 1 \\
\hline TK2 & Recessive & Multiple deletions & 3 & 2 \\
\hline$P O L G 2$ & Dominant & Multiple deletions & 3 & 3 \\
\hline$A F G 3 L 2$ & Dominant & Multiple deletions & 2 & 1 \\
\hline DGUOK & Recessive & Multiple deletions & 2 & 1 \\
\hline DNA2 & Dominant & Multiple deletions & 1 & 1 \\
\hline MPV17 & Recessive & Multiple deletions & 1 & 1 \\
\hline
\end{tabular}

${ }^{1}$ Three patients had digenic mutations i.e. mutations of two different nuclear genes.

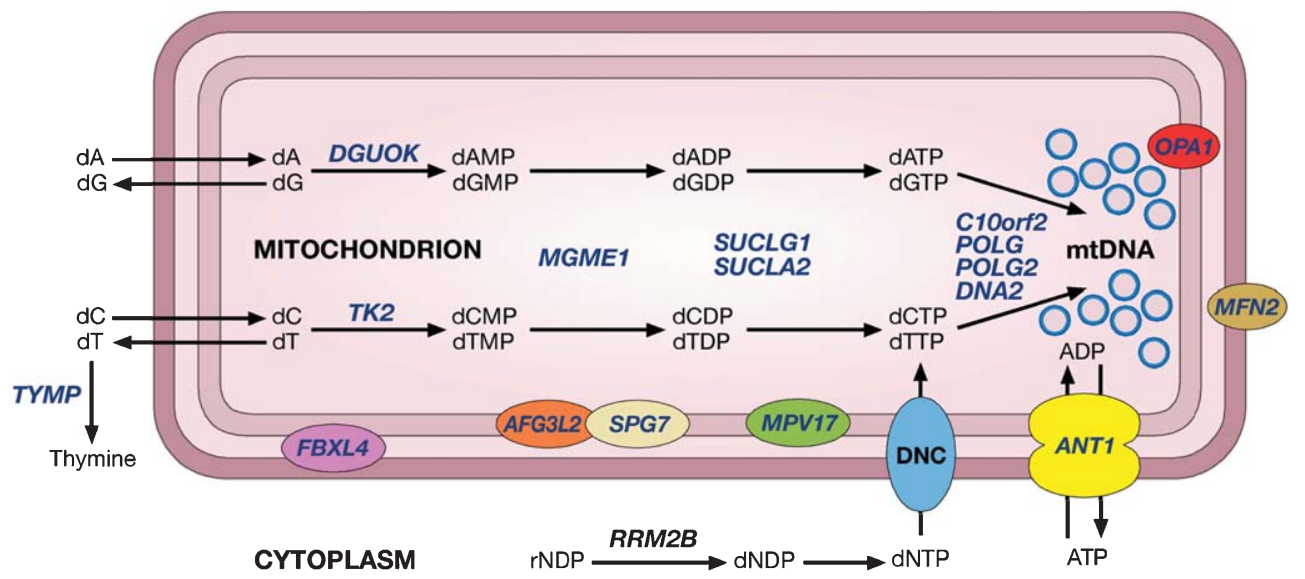

Fig. 3. Mendelian disorders of mtDNA maintenance. A cartoon of mitochondrial nucleotide metabolism for mtDNA synthesis, replication and repair identifying the major genes (italicised in blue) which have been associated with disorders of mtDNA maintenance including adult-onset PEO and multiple mtDNA deletion syndromes and/or mtDNA depletion and the sub-mitochondrial localisation of the proteins encoded by these genes.

Patients had depleted thymidine phosphorylase activity that was characteristically below $5 \%$ of controls. Gastrointestinal dysmotility is the cardinal feature of MNGIE, although highly variable in severity; common symptoms included borborygmi, abdominal pain, diarrhoea, vomiting, and early satiety. Almost universally patients were cachectic and reported weight loss in later life. Gastrointestinal dysmotility was reported in several patients with other known PEO genes, including one patient with recessive $R R M 2 B$ mutations and mtDNA depletion [14], but without depleted thymidine phosphorylase activity. MNGIE phenotype has also been reported due to mutations in POLG. Thymidine concentrations are not increased in these patients, similar to that seen in $R R M 2 B$, and leukoencephalopathy, which is typical for TYMP mutations, is conspicuously absent in these cases [15]. Myopathies were reported in nearly all cases and included muscle weakness and atrophy. Peripheral and sensory neuropathies (including absence of joint reflexes) were also common. Other features included retinopathy, hearing loss, or both [13, 16-27]. One peculiar patient with a late-onset 
phenotype had compound mutations of TYMP and C10ORF2, with no evidence of mtDNA instability [28], which may explain late manifestation of symptoms. Gastrointestinal dysmotility was not reported in three patients [21, 29]. However, given the distinct, progressive phenotype, gastrointestinal symptoms were predicted to present later in life.

Many patients were excluded due to the earlyonset presentation of symptoms, while a small number presented after the age of 30. Therefore, MNGIE is an adolescent to early adult-onset disease. TYMP mutations are rare, but the phenotype is distinct. Nevertheless, there remains a poor correlation between mutations, age of onset and severity.

\section{SLC25A4 - ADP/ATP translocase 1}

SLC25A4 (ANT1) encodes ADP/ATP translocase 1 and is required for the exchange of ADP from the cytoplasm with ATP generated by the mitochondria [30]. Indolent or mild PEO phenotypes, with or without ptosis, were described in 39 patients with SLC25A4 mutations. Neuromuscular symptoms were largely confined to the extra ocular and facial muscles [6, 31-33]. Hypoacusia and generalised muscle weakness were also reported in two unrelated families [6]. Diabetes was reported in one patient [34] whilst four adult PEO patients harbouring SLC25A4 mutations manifest psychiatric symptoms [32, 34, 35].

While SLC25A4 mutations are indicative of autosomal dominant, mild adult-onset PEO phenotypes, neuropathies and psychiatric symptoms expand the clinical spectrum. Although a rare cause of adult-onset PEO, SLC25A4 should be sequenced in suspected patients with mild or indolent PEO phenotypes.

\section{POLG - DNA polymerase subunit gamma-1}

Mutations of $P O L G$, encoding the catalytic subunit of the only known DNA polymerase of mitochondria, are amongst the most common pathogenic mutations found in individuals presenting with PEO and multiple mtDNA deletions. This review identified 258 adultonset PEO patients with mutations in POLG. First identified as a locus for PEO by Van Goethem et al. (2001), POLG-related disorders have shown to manifest as a broad phenotypic continuum of overlapping symptoms in patients with mitochondrial disorders [36].

POLG related mitochondrial disease is historically classified according to clinical manifestations and although most patients may not exhibit all phenotypic features, clustering of symptoms may aid clinical recognition and aid diagnosis. The following syndromes are recognised: 1) arPEO, usually characterised by isolated PEO and ptosis; 2) adPEO is frequently associated with myopathy and other systemic features; 3) ataxia neuropathy spectrum (ANS) combines the previous syndromes of mitochondrial recessive ataxia syndrome (MIRAS) and sensory ataxia neuropathy, dysarthria and ophthalmoplegia (SANDO), in which cardinal features of ataxia and neuropathy manifest in over $90 \%$ of individuals, with other clinical features presenting to a lesser degree including seizures $(\approx 65 \%)$ and PEO $(\approx 50 \%)$. Myopathy is rare. Myoclonic epilepsy myopathy sensory ataxia (MEMSA) now envelops the syndrome of spinocerebellar ataxia with epilepsy (SCAE) and includes epilepsy, myopathy, and ataxia without PEO [37]. Two other syndromic disorders related to POLG are recognised to present in childhood and include Alpers-Huttenlocher syndrome (AHS) and Childhood myocerebrohepatopathy spectrum (MCHS) disorder, but are not within the remit of this review. Additional, non-syndromic clinical features have been described.

Ataxia was a frequent clinical feature in adult-onset PEO patients with mutations in $P O L G$; having been reported in over $40 \%$ of cases; a figure not dissimilar to the incidence reported in a previous multicenter case series [36]. Ataxia was specifically related to the presence of an often debilitating peripheral sensory neuronopathy [38] in over $20 \%$ of adult-onset PEO patients with mutations in POLG (Supplementary Table 7). We would suggest, however, that these figures may represent an under estimation as only more recent publications have discerned between peripheral and central components of ataxia, that is, ataxia due either to cerebellar dysfunction or pathology of the dorsal root ganglion. Premature ovarian failure (POF) was also observed in a small number of female patients $[15,39,40]$. Other symptoms included dysphagia, dysarthria and diabetes mellitus. Psychiatric symptoms were particularly prevalent in patients harboring mutations of $P O L G$. Parkinsonism was described in 38 patients [35, 40-57]. Dementia was reported more frequently than would be expected by chance $[36,56$, 58-61] as was depression [15, 35, 40, 41, 45, 50, 54, $55,62-66]$. POLG-related encephalopathy was a hallmark feature in patients comprising of, but not limited to, seizure disorders (status epilepticus, myoclonus, grand mal seizures) and neurological manifestations, comparable to mitochondrial encephalopathy, lactic acidosis and stroke-like episodes syndrome (MELAS) $[36,39,46-49,54,58,60-66]$; with the conspicuous 
absence of temporal lobe involvement [67, 68]. MNGIE-like phenotypes with preserved thymidine phosphorylase levels have also been reported in $P O L G$ patients [15].

This review identified 85 different mutations in $P O L G$ presenting as adult-onset PEO. These were mainly missense mutations demonstrating dominant inheritance or occurring sporadically (Supplementary Table 8). There was great disparity in the frequency of mutations; the most commonly occurring were the p.(Ala467Thr), p.(Trp748Ser), and p.(Thr251Ile) p.(Pro587Leu) mutations (Supplementary Table 8). The most prevalent pathogenic mutation in $P O L G$ reported in the Caucasian population is a c.1399G $>\mathrm{A}$ leading to p.(Ala467Thr) missense mutation in the linker domain of the protein [69]. Although, the homozygous p.(Ala467Thr) POLG mutation was originally reputed to cause discrete phenotypes, this has subsequently been revised to a continuum of clinical symptoms and hence demonstrates the underlying challenge of diagnosing POLG-related PEO.

\section{C10ORF2 - twinkle}

C10ORF2 encodes the mitochondrial protein twinkle, a DNA helicase that catalyses the ATP-dependent unwinding of mtDNA in the 5' to 3' direction, essential for mtDNA replication, and co-localises with mtDNA in mitochondrial nucleoids $[4,70]$. Both adPEO and arPEO was reported in 143 patients with C10ORF2 mutations, presenting a broad phenotypic spectrum. Proximal and facial muscle weakness, gait disturbance, exercise intolerance and fatigue were particularly prevalent. Other clinical manifestations included diabetes mellitus, visual loss or impairment, diplopia, hearing loss, ataxia, and seizures [71-73].

Parkinsonism was described in seven patients, including one with compound mutations of C10ORF2 and TYMP [27]. Psychiatric symptoms were particularly prevalent and included depression, avoidant personalities, migraines, dementia, and Alzheimer's disease $[4,71,72,74]$. Scattered white matter lesions were also found in a single case, but with no apparent psychiatric or stroke-like symptoms [75].

Cardiac involvement was also reported, including one patient with right bundle branch block [76], and left ventricular hypertrophy in a sizeable cohort of patients [9]; whilst coronary artery involvement was peculiar to a Chinese family with familial heart disease [77]. Congestive cardiac failure was described in a mixed consanguineous Saudi Arabian family with a dominant mutation, who also presented with severe hepatopathy and acute encephalopathy [78]. Multiple mtDNA deletions were detected in all patients where such analyses were performed, but were not always prominent. Depletion was detected in one patient, in addition to multiple mtDNA deletions [79]. Recessively inherited mutations generally resulted in a severe early-onset phenotype, but again there was no clear genotype-phenotype correlation. Given the broad phenotypic spectrum, sequencing of C10ORF2 should be considered for all suspected adult-onset PEO patients, particularly those with psychiatric symptoms.

\section{OPA1 - dynamin-like 120 kDa protein}

OPA 1 encodes the mitochondrial dynamin-like 120 $\mathrm{kDa}$ protein localises to the mitochondrial inner membrane and is important for regulation of mitochondrial fusion and morphology [80,81]. The review criteria were amended for patients with OPAl mutations to allow patients with onset of symptoms before 16 years old to be included; the $O P A 1$ phenotype typically presented from birth or early in life. The 42 PEO patients with heterozygous $O P A 1$ mutations presented with optic atrophy and visual loss, often leading to blindness and sometimes colour vision abnormalities in the first decade of life. PEO and mitochondrial symptoms occurred in adult life, with many patients also harbouring multiple mtDNA deletions. Sensorineural hearing loss was the most prominent of these symptoms, and was almost universal in all patients. Ataxia, axonal neuropathy, ptosis, muscle weakness and exercise intolerance were also frequently described. Migraines, diabetes, dementia and epilepsy were described in some patients, expanding the phenotypic spectrum [82]. Hypogonadism and macrocytic anaemia were reported in one patient who was initially diagnosed with a heterozygous $P O L G 2$ mutation [83].

OPAl mutations had been previously reported as an important cause of dominant optic atrophy and visual loss, with other symptoms increasingly recognised after the first described cases [84]. Optic atrophy in childhood followed by ophthalmoplegia in adult life had also been reported earlier in the literature, but initially had been genetically undetermined [85, 86]. The phenotype is similar to Leber Hereditary Optic Neuropathy (LHON), where three mtDNA point mutations (m.3460G $>$ A, m.11778G $>$ A, and m.14484T $>$ C) accounted for over $90 \%$ of patients of patients in the north east of England, with a predicted overall population prevalence of one in 25,000 [87].

Phenotypically, OPAl mutations are distinct and should be considered in all patients presenting with 
optic atrophy in childhood, irrespective if mitochondrial disease is suspected.

\section{POLG2 - DNA polymerase subunit gamma-2}

POLG2 encodes the mitochondrial DNA polymerase accessory subunit and binds to single-stranded DNA, which is necessary for mtDNA replication and embryogenesis [88].

Three adult-onset PEO patients, harbouring heterozygous POLG2 mutations, all presented with PEO, ptosis and muscle weakness to varying degrees. However, a broad range of additional symptoms was described. One patient had marked ataxia and cerebellar features and was unable to tandem gait [89]. Another patient presented with gastrointestinal symptoms and a dystrophy-like distribution of muscle weakness [90]. The third patient presented with a cardiac conduction defect and had impaired glucose tolerance [91]. Although presenting with a broad spectrum of symptoms, PEO and ptosis with a proximal myopathy was present in all three patients. Classification of POLG2 mutations remains difficult due to the small number of patients reported, although a number of early-onset patients with recessive mutations had also been described [90]. POLG2 screening should be considered in all suspected adult-onset PEO patients, but is a rare cause of mitochondrial disease.

\section{RRM2B - ribonucleoside-diphosphate reductase subunit $M 2 B$}

$R R M 2 B$ encodes ribonucleoside-diphosphate reductase subunit M2 B (p53R2), is important for DNA repair and is inactivated in many cancers [92]. It has a similar role in the maintenance and repair of mtDNA, but is also essential for dNTP supply for mtDNA replication [93].

Similar to $P O L G$ and C10ORF2, RRM2B mutations resulted in a broad phenotypic spectrum in 42 adult-onset PEO patients. This included mild PEO, with or without ptosis, muscle weakness and exercise intolerance [5]. Hearing loss was also frequently reported, while muscle atrophy and fatigue was also prevalent [10, 94, 95]. Anxiety and depression was reported in one patient [10]. The MNGIE-like phenotype was described in one patient with mtDNA depletion [14], and was comparable to early-onset patients with $R R M 2 B$ mutations [93].

$R R M 2 B$ mutations, representing the third largest number of adult-onset PEO patients, present broad symptoms in patients, but are unlikely to be the cause of multisystem disorders. Overall, this suggests that $R R M 2 B$ should be sequenced in all suspected patients with adult-onset PEO; particularly in those manifesting additional systemic features including bulbar, hearing loss and gastrointestinal dysmotility.

\section{TK2 - thymidine kinase 2}

TK2 encodes thymidine kinase 2, which phosphorylates thymidine, deoxycytidine, and deoxyuridine and is essential for dNTP generation for mtDNA replication. Three patients have been reported to date with recessive $T K 2$ mutations with multiple mtDNA deletions and presented late in life. Two sisters presented with ptosis in the fourth and fifth decades of life, which progressed to ophthalmoparesis and proximal muscle weakness [8]. Scapular winging, dysphagia, and respiratory deficiency were common to both. One sibling also had evidence of skin sarcoidosis and mild muscle atrophy. The third unrelated patient had sensorineural hearing loss with mild ptosis, subtle PEO, facial weakness, proximal muscle wasting, including scapular winging and weakness of sternocleidomastoids, and neck flexion [96].

All three patients had late onset and slowly progressive myopathies including respiratory insufficiency, in addition to central nervous system involvement [8]. Depletion disorders related to $T K 2$ mutations are often more severe and lead to premature death [97]. Mutations of TK2 leading to PEO are apparently rare, but should be considered where generalised muscle weakness and wasting and respiratory failure are prominent.

\section{DGUOK - deoxyguanosine kinase}

DGUOK encodes deoxyguanosine kinase and is required for the first step of salvage of deoxyribonucleotides in the mitochondria, essential to mitochondrial genome maintenance [98]. Disease onset in two patients with recessive $D G U O K$ mutations was very late in life [11]. The first patient presented with isolated PEO and ptosis at age 58 years. Marked exercise intolerance was also reported in a sibling. The second patient presented with bilateral ptosis and PEO in their sixth decade of life and complained of upper and lower limb girdle weakness with leg cramps in later life. Occasional dysphagia for liquids was also reported. Family history was negative for muscle disorders. Both patients harboured recessive DGUOK mutations that had been previously reported in earlyonset mitochondrial disease patients with mtDNA depletion [99]. DGUOK mutations remain associated 
in early-onset mitochondrial disease causing hepatocerebral mitochondrial depletion [100] and a very rare cause of late-onset PEO.

\section{MPV17 - protein MPV17}

The role of protein MPV17 in mitochondrial maintenance, encoded by $M P V 17$, remains poorly understood, but it is known to localise to the mitochondrial inner membrane [101]. A single patient who presented with distal limb weakness and numbness at 34 years old [102] was initially diagnosed with Charcot-Marie tooth disease after nerve conduction studies and EMG results. This progressed to proximal limb weakness, exercise intolerance, diabetes mellitus, ptosis, ophthalmoparesis, hearing loss, severe constipation due to gastrointestinal dysmotility, and depression in the fifth decade of life. At 65 years the patient developed parkinsonism characterised by bradykinesia, bilateral resting tremor, and mild rigidity. The patient also had a fatty liver and interestingly a sibling died of unexplained liver failure at 39 years old.

MPV17 mutations had previously been reported in early-onset mitochondrial disease with mtDNA depletion [103] with ophthalmoplegia, axonal sensorymotor neuropathy and preceding liver dysfunction observed, whereas parkinsonism and gastrointestinal symptoms were additional features. Therefore, MPV17 mutations are an apparently rare cause of adult-onset mitochondrial disease.

\section{MGME1 - mitochondrial genome maintenance exonuclease 1}

MGME1 (C20ORF72) encodes mitochondrial genome maintenance exonuclease 1. MGME1 is essential for mitochondrial genome maintenance by cleaving single-stranded DNA and processing DNA flap substrates, while also necessary for maintaining 7S DNA levels [104, 105].

Three patients have presented with mild bilateral ptosis followed by progressive ophthalmoplegia late in life [104]. Proximal muscle weakness, generalised muscle wasting, respiratory deficiency and dyspnea were characteristic in all patients. Chronic renal failure, cardiac arrhythmias, depressive episodes, and memory lapses were reported in one patient, while two affected brothers had mild kyphosis. Although the patients presented with a similar phenotype, there were no other cases in the literature to allow comparison.

\section{DNA2 - DNA replication ATP-dependent helicase/nuclease DNA2}

Studies of DNA2 are limited, but suggest that hDNA2 co-localises with a subfraction of mitochondrial nucleoids containing mtDNA but is also present in the nucleus [106]. Levels of hDNA2 accumulated within the nucleoids with disease-associated mutations of twinkle, whereas depletion led to a decrease of mtDNA replication intermediates and inefficient repair of damaged mtDNA, suggesting a role in nuclear and $\mathrm{mtDNA}$ repair maintenance. One patient, harbouring a heterozygous mutation with multiple mtDNA deletions, had lower limb weakness, ophthalmoplegia, diplopia and myalgia at 55 years old, with onset at 35 years old [107]. This progressive myopathy was similarly observed in early-onset patients with DNA2 mutations. With only one adult patient reported, DNA2 mutations are therefore an extremely rare cause of adult-onset mitochondrial disease.

\section{SPG7 - paraplegin}

SPG7 encodes paraplegin, which localises to the mitochondrial inner membrane [108]. Twelve patients with SPG7 mutations and PEO with multiple mtDNA deletions who met the review criteria were reported using whole exome sequencing [109, 110]. Nine patients presented with the classic spastic paraplegia phenotype observed in previously reported patients [108], whereby PEO and multiple mtDNA deletions were previously unreported. Six patients had cerebellar atrophy evident on MRI imaging. Compound $S P G 7$ mutations were identified in eight patients, while four had heterozygous mutations, including one patient with isolated PEO. However, the typical presentation was onset of either PEO/ptosis and spastic ataxia, or a progressive ataxia disorder. Strikingly, eleven patients were identified from a cohort of 68 patients with undiagnosed PEO and multiple mtDNA deletions [109], indicating that $S P G 7$ mutations are a common cause of adult-onset PEO and should be sequenced in patients with undetermined PEO.

\section{AFG3L2 - AFG3-like protein 2}

AFG3L2 encodes AFG3-like protein 2, which forms a homo-oligomer, an m-AAA protease, with paraplegin in the mitochondrial inner membrane [111, 112]. Whole exome sequencing identified two patients with dominant AFG3L2 mutations [113]. Both presented with late-onset, slowly progressive ptosis and 
Table 2

Summary of body systems affected by adult-onset PEO gene mutations

\begin{tabular}{|c|c|c|c|c|c|c|c|c|c|}
\hline Gene & Muscle & $\begin{array}{c}\text { Central Nervous } \\
\text { System (CNS) }\end{array}$ & Psychiatric & Cardiovascular & Endocrine & Digestive & Respiratory & Reproductive & Urinary \\
\hline$P O L G$ & ++ & ++ & + & + & + & + & - & + & - \\
\hline C1OORF2 & ++ & + & ++ & + & + & + & - & + & - \\
\hline$T Y M P$ & ++ & ++ & + & - & - & ++ & - & - & - \\
\hline$R R M 2 B$ & ++ & ++ & + & + & - & + & + & - & + \\
\hline OPA1 & ++ & ++ & + & - & - & + & - & - & - \\
\hline$S L C 25 A 4$ & ++ & + & + & - & + & - & - & - & - \\
\hline SPG7 & ++ & ++ & + & - & - & - & - & - & + \\
\hline$M G M E 1$ & ++ & - & + & + & - & - & ++ & - & + \\
\hline$T K 2$ & ++ & + & - & - & - & - & + & - & - \\
\hline POLG2 & ++ & ++ & - & - & - & + & + & - & - \\
\hline$A F G 3 L 2$ & ++ & ++ & - & - & - & - & - & - & - \\
\hline$D G U O K$ & ++ & - & - & - & - & - & - & - & - \\
\hline DNA2 & ++ & - & - & - & - & - & - & - & - \\
\hline MPV17 & ++ & ++ & ++ & - & ++ & ++ & - & - & - \\
\hline
\end{tabular}

${ }^{++}$denotes body systems frequently affected by mutations. ${ }^{+}$denotes body systems rarely affected by mutations. ${ }^{-}$denotes mutations that are not affected by mutations.

ophthalmoparesis with slurred speech and lower limb muscle weakness. The first patient had a family history of ataxia and had an indolent gait and limb ataxia seen in her teens, progressing to a broad-based ataxic gait upon clinical examination, with dysmetria and dysarthria. The second patient had slowly progressive ataxia and lower limb spasticity with marked cerebellar atrophy, but without prior family history.

AFG3L2 mutations had typically been associated with autosomal dominant spinocerebellar ataxia 28 (SCA28) [112]. Thus far, with only two patients currently reported, $A F G 3 L 2$ mutations are therefore a rare cause of PEO with multiple mtDNA deletions. Nevertheless, $A F G 3 L 2$ sequencing should be considered for patients presenting with PEO and ataxia, spasticity, or both.

\section{DISCUSSION}

We have identified fourteen nuclear genes (twelve systematically) whereby mutations lead to adult-onset PEO with mtDNA instability. A total of 583 patients with a confirmed genetic diagnosis were described in 160 articles, with large variation in the quality of patient reporting. A further fourteen patients with either $S P G 7$ or $A F G 3 L 2$ mutations were also recently reported in three papers, giving a total of 597 patients in 163 articles who met the review criteria. Those describing patients in the greatest detail were considered of a high quality. Age of onset was not reported for many patients, particularly those detailed in large patient cohorts. Also, mtDNA instability was not determined for all patients, perhaps due to a lack of skeletal muscle tissue available. Furthermore, the diverse symptoms and phenotypes presented by the patients meant that a meta-analysis and statistical comparisons was not possible.

This systematic review has confirmed the broad spectrum of symptoms affecting multiple body systems in adult-onset PEO patients with mtDNA instability with adPEO the predominant manner of inheritance (Table 2). While genotype-phenotype correlates remain challenging clear clinical patterns are emerging. POLG and C10ORF2 mutations present with the broadest phenotypes, and represent over $65 \%$ of all patients in the literature (Table 1). Yet, PEO, ptosis and proximal muscle weakness are perceived as prominent clinical features in adult patients with mutations in both POLG and C1OORF2. It is not uncommon for the same heterozygous POLG or C1OORF2 mutations to cause different clinical manifestations, reflecting the vast complexity of PEO. SLC25A4 and C10ORF2 mutations generally result in indolent PEO phenotypes, with or without mild proximal muscle weakness, whilst POLG2 mutations often present with a proximal myopathy that is universally present in all patients. Parkinsonism in late onset PEO cases would suggest screening for $P O L G$ mutations. Sensory ataxia is also prominent and suggestive of $P O L G$ mutations. Additional systemic features including bulbar, hearing loss and gastrointestinal dysmotility should preferentially direct testing towards $R R M 2 B$ genetic analysis. Screening for $T K 2$ mutations should be considered in cases of suspected mtDNA maintenance disorders and late onset-myopathy in which respiratory failure is prominent. Proximal muscle weakness, generalised muscle wasting, emaciation and respiratory failure are 
also prominent features in patients with $M G M E 1$ mutations. However, these patients classically present at an earlier age than those harbouring TK2 mutations.

Mutations in three PEO genes exhibit discreet characteristic phenotypes including TYMP, OPAl and SPG7. Recessive TYMP mutations cause the fatal multisystem disorder MNGIE, characterised by marked gastrointestinal dysmotility with age of presentation often ranging from the first to third decades of life [7]. Autosomal dominant or sporadic OPA1 mutations frequently present with optic atrophy and varying degrees of visual loss in early-life, followed by ophthalmoparesis, hearing loss and mitochondrial myopathy in adult-life [84]. And most recently, spastic ataxia is recognised as a cardinal clinical finding in adult-PEO patients harbouring SPG7 mutations [109, 110].

Nevertheless, although clinical patterns are emerging, clinical manifestations still remain varied and this should not deter screening of all maintenance disorder genes in suspected mitochondrial disease patients with $\mathrm{PEO}$, if initial genetic testing proves negative.

\section{CONCLUSION}

In many cases of PEO, the underlying genetic defect remains either due to a single large scale rearrangement of mtDNA or point mutation. However, a considerable group of PEO patients is increasingly recognised, who harbour multiple mtDNA deletions in skeletal muscle.

PEO remains the most common presenting neurological hallmark seen in adults with mtDNA maintenance disorders, with the clinical phenotype quite often not restricted to extraocular muscles. Despite marked clinical overlap between mitochondrial maintenance genes, key clinical features are emerging that will help direct prioritization of genetic testing and screening of variants identified by whole exome and whole genome studies and may, eventually, preclude the need for a muscle biopsy. Careful clinical evaluation documenting personal and family history, and the use of supportive clinical investigations to document the extent of phenotype are key to building clinical evidence in support of genetic diagnoses that will provide both patients and physicians with guidance about diagnosis, future prognosis and evaluation of potential therapeutic strategies.

\section{ACKNOWLEDGMENTS}

We acknowledge the financial support of a Wellcome Trust Strategic Award (096919Z/11/Z), the
Medical Research Council (UK) Centre for Translational Muscle Disease research (G0601943), the Medical Research Council (UK) Mitochondrial Disease Patient Cohort (G0800674) and the UK NHS Highly Specialised "Rare Mitochondrial Disorders of Adults and Children" Service. PFC is a Wellcome Trust Senior Fellow in Clinical Science (084980/Z/08/Z), a UK NIHR Senior Investigator and receives additional support from EU FP7 TIRCON.

\section{CONFLICT OF INTEREST}

The authors have no conflict of interest to report.

\section{SUPPLEMENTARY MATERIAL}

The supplementary material is available in the electronic version of this article: http://dx.doi.org/10.3233/ JND-140041.

\section{REFERENCES}

[1] Zeviani, M., Servidei, S., Gellera, C., Bertini, E., DiMauro, S., DiDonato S. An autosomal dominant disorder with multiple deletions of mitochondrial DNA starting at the D-loop region. Nature. 1989; 339(6222): 309-311.

[2] Moraes, C. T., DiMauro, S., Zeviani, M., Lombes, A., Shanske, S., Miranda, A. F., Nakase, H., Bonilla, E., Werneck, L. C., Servidei, S., Nonaka, I., Koga, Y., Spiro, A. J., Brownell A. K. W., Schmidt, B., Schotland, D. L., Zupanc, M., DeVivo, D. C., Schon, E. A., Rowland, L. P. Mitochondrial DNA deletions in progressive external ophthalmoplegia and Kearns-Sayre syndrome. New Engl J Med. 1989; 320(20): 1293-1299.

[3] Van Goethem, G., Dermaut, B., Löfgren, A., Martin, J. J., Van Broeckhoven, C. Mutation of $P O L G$ is associated with progressive external ophthalmoplegia characterized by mtDNA deletions. Nat Genet. 2001; 28(3): 211-212.

[4] Spelbrink, J. N., Li, F. Y., Tiranti, V., Nikali, K., Yuan, Q. P., Tariq, M., Wanrooij, S., Garrido, N., Comi, G., Morandi, L., Santoro, L., Toscano, A., Fabrizi, G. M., Somer, H., Croxen, R., Beeson, D., Poulton, J., Suomalainen, A., Jacobs, H. T., Zeviani, M., Larsson, C. Human mitochondrial DNA deletions associated with mutations in the gene encoding Twinkle, a phage T7 gene 4-like protein localized in mitochondria. Nat Genet. 2001; 28(3): 223-231.

[5] Tyynismaa, H., Ylikallio, E., Patel, M., Molnar, M. J., Haller, R. G., Suomalainen, A. A heterozygous truncating mutation in $R R M 2 B$ causes autosomal-dominant progressive external ophthalmoplegia with multiple mtDNA deletions. Am J Hum Genet. 2009; 85(2): 290-295.

[6] Kaukonen, J., Juselius, J. K., Tiranti, V., Kyttälä A, Zeviani, M., Comi, G. P., Keränen, S., Peltonen, L., Suomalainen, A. Role of adenine nucleotide translocator 1 in mtDNA maintenance. Science. 2000; 289(5480): 782-785.

[7] Nishino, I., Spinazzola, A., Hirano, M. Thymidine phosphorylase gene mutations in MNGIE, a human mitochondrial disorder. Science. 1999; 283(5402): 689-692. 
[8] Tyynismaa, H., Sun, R., Ahola-Erkkilä S, Almusa, H., Pöyhönen, R., Korpela, M., Honkaniemi, J., Isohanni, P., Paetau, A., Wang, L., Suomalainen, A. Thymidine kinase 2 mutations in autosomal recessive progressive external ophthalmoplegia with multiple mitochondrial DNA deletions. Hum Mol Genet. 2012; 21(1): 66-75.

[9] Fratter, C., Gorman, G. S., Stewart, J. D., Buddles, M., Smith, C., Evans, J., Seller, A., Poulton, J., Roberts, M., Hanna, M. G., Rahman, S., Omer, S. E., Klopstock, T., Schoser, B., Kornblum, C., Czermin, B., Lecky, B., Blakely, E. L., Craig, K., Chinnery, P. F., Turnbull, D. M., Horvath, R., Taylor, R. W. The clinical, histochemical, and molecular spectrum of PEO1 (Twinkle)-linked adPEO. Neurology. 2010; 74(20): 1619-1626.

[10] Takata, A., Kato, M., Nakamura, M., Yoshikawa, T., Kanba, S., Sano, A., Kato, T. Exome sequencing identifies a novel missense variant in $R R M 2 B$ associated with autosomal recessive progressive external ophthalmoplegia. Genome Biol. 2011; 12(9): R92.

[11] Ronchi, D., Garone, C., Bordoni, A., Gutierrez Rios, P., Calvo, S. E., Ripolone, M., Ranieri, M., Rizzuti, M., Villa, L., Magri, F., Corti, S., Bresolin, N., Mootha, V. K., Moggio, M., DiMauro, S., Comi, G. P., Sciacco, M. Next-generation sequencing reveals DGUOK mutations in adult patients with mitochondrial DNA multiple deletions. Brain. 2012; 135(11): 3404-3415.

[12] El-Hattab, A. W., Scaglia, F. Mitochondrial DNA depletion syndromes: Review and updates of genetic basis, manifestations, and therapeutic options. Neurotherapeutics. 2013; 10(2): 186-198.

[13] Nishino, I., Spinazzola, A., Papadimitriou, A., Hammans, S., Steiner, I., Hahn, C. D., Connolly, A. M., Verloes, A., Guimarães, J., Maillard, I., Hamano, H., Donati, M. A., Semrad, C. E., Russell, J. A., Andreu, A. L., Hadjigeorgiou, G. M., Vu, T. H., Tadesse, S., Nygaard, T. G., Nonaka, I., Hirano, I., Bonilla, E., Rowland, L. P., DiMauro, S., Hirano, M. Mitochondrial neurogastrointestinal encephalomyopathy: An autosomal recessive disorder due to thymidine phosphorylase mutations. Ann Neurol. 2000; 47(6): 792800 .

[14] Shaibani, A., Shchelochkov, O. A., Zhang, S., Katsonis, P., Lichtarge, O., Wong, L. J., Shinawi, M. Mitochondrial neurogastrointestinal encephalopathy due to mutations in RRM2B. Arch Neurol. 2009; 66(8): 1028-1032.

[15] Van Goethem, G., Löfgren, A., Dermaut, B., Ceuterick, C., Martin, J. J., Van Broeckhoven, C. Digenic progressive external ophthalmoplegia in a sporadic patient: Recessive mutations in POLG and C10orf2/Twinkle. Hum Mutat. 2003; 22(2): 175-176

[16] Amiot, A., Tchikviladzé, M., Joly, F., Slama, A., Hatem, D. C., Jardel, C., Messing, B., Lombès, A. Frequency of mitochondrial defects in patients with chronic intestinal pseudoobstruction. Gastroenterology. 2009; 137(1): 101-109.

[17] Blazquez, A., Martín, M. A., Lara, M. C., Martí, R., Campos, Y., Cabello, A., Garesse, R., Bautista, J., Andreu, A. L., Arenas, J. Increased muscle nucleoside levels associated with a novel frameshift mutation in the thymidine phosphorylase gene in a Spanish patient with MNGIE. Neuromuscul Disord 2005; 15(11): 775-778.

[18] Blondon, H., Polivka, M., Joly, F., Flourie, B., Mikol, J., Messing, B. Digestive smooth muscle mitochondrial myopathy in patients with mitochondrial-neuro-gastrointestinal encephalomyopathy (MNGIE): Report of 3 cases and review of the literature. Gastroenterol Clin Biol. 2005; 29(8-9): 773-778.
[19] Carrozzo, R., Hirano, M., Fromenty, B., Casali, C., Santorelli, F. M., Bonilla, E., DiMauro, S., Schon, E. A., Miranda, A. F. Multiple mtDNA deletions features in autosomal dominant and recessive diseases suggest distinct pathogeneses. Neurology. 1998; 50(1): 99-106.

[20] Etienne, G., Shamseddine, K., Pulley, M., Milfred, F. Two new gene mutations for late onset mitochondrial neurogastrointestinal encephalopathy (MNGIE). Transl Neurosci. 2012; 3(4): 413-414.

[21] Filosto, M., Scarpelli, M., Tonin, P., Testi, S., Cotelli, M. S., Rossi, M., Salvi, A., Grottolo, A., Vielmi, V., Todeschini, A., Fabrizi, G. M., Padovani, A., Tomelleri, G. Pitfalls in diagnosing mitochondrial neurogastrointestinal encephalomyopathy. J Inherit Metab Dis. 2011; 34(6): 11991203.

[22] Hamano, H., Ohta, T., Takekawa, Y., Kouda, K., Shinohara, Y. Mitochondrial neurogastrointestinal encephalomyopathy presenting with protein-losing gastroenteropathy and serum copper deficiency: A case report. Clinical Neurology. 1997; 37(10): 917-922.

[23] Hirano, M., Garcia-de-Yebenes, J., Jones, A. C., Nishino, I., DiMauro, S., Carlo, J. R., Bender, A. N., Hahn, A. F., Salberg, L. M., Weeks, D. E., Nygaard, T. G. Mitochondrial neurogastrointestinal encephalomyopathy syndrome maps to chromosome 22q13.32-qter. Am J Hum Genet. 1998; 63(2): 526-533.

[24] Hirano, M., Silvestri, G., Blake, D. M., Lombes, A., Minetti, C., Bonilla, E., Hays, A. P., Lovelace, R. E., Butler, I., Bertorini, T. E., Threlkeld, A. B., Mitsumoto, H., Salberg, L. M., Rowland, L. P., DiMauro, S. Mitochondrial neurogastrointestinal encephalomyopathy (MNGIE): Clinical, biochemical, and genetic features of an autosomal recessive mitochondrial disorder. Neurology. 1994; 44(4): 721-727.

[25] Laforce, R., Valdmanis, P. N., Dupre, N., Rouleau, G. A., Turgeon, A. F., Savard, M. A novel TYMP mutation in a French Canadian patient with mitochondrial neurogastrointestinal encephalomyopathy. Clin Neurol and Neurosurg. 2009; 111(8): 691-694.

[26] Martí R, Verschuuren, J. J., Buchman, A., Hirano, I., Tadesse, S., van Kuilenburg, A. B., van Gennip, A. H., Poorthuis, B. J., Hirano, M. Late-onset MNGIE due to partial loss of thymidine phosphorylase activity. Ann Neurol. 2005; 58(4): 649-652.

[27] Massa, R., Tessa, A., Margollicci, M., Micheli, V., Romigi, A., Tozzi, G., Terracciano, C., Piemonte, F., Bernardi, G., Santorelli, F. M. Late-onset MNGIE without peripheral neuropathy due to incomplete loss of thymidine phosphorylase activity. Neuromuscul Disord. 2009; 19(12): 837-840.

[28] Nakhro, K., Chung, K. W., Kim, S. M., Sunwoo, I. N., Cho, E. M., Park, S. W., Hwang, J. H., Choi, B. O. Compound mutations of PEOI and TYMP in a progressive external ophthalmoplegia patient with incomplete mitochondrial neurogastrointestinal encephalomyopathy phenotype. Genes Genom. 2011; 33(4): 431-437.

[29] Gamez, J., Ferreiro, C., Accarino, M. L., Guarner, L., Tadesse, S., Martí, R. A., Andreu, A. L., Raguer, N., Cervera, C., Hirano, M. Phenotypic variability in a Spanish family with MNGIE. Neurology. 2002; 59(3): 455-457.

[30] Stepien, G., Torroni, A., Chung, A. B., Hodge, J. A., Wallace, D. C. Differential expression of adenine nucleotide translocator isoforms in mammalian tissues and during muscle cell differentiation. J Biol Chem. 1992; 267(21): 14592-14597.

[31] Deschauer, M., Hudson, G., Müller, T., Taylor, R. W., Chinnery, P. F., Zierz S. A novel ANT1 gene mutation with 
probable germline mosaicism in autosomal dominant progressive external ophthalmoplegia. Neuromuscul Disord. 2005; 15(4): 311-315.

[32] Komaki, H., Fukazawa, T., Houzen, H., Yoshida, K., Nonaka, I., Goto, Y. A novel D104G mutation in the adenine nucleotide translocator 1 gene in autosomal dominant progressive external ophthalmoplegia patients with mitochondrial DNA with multiple deletions. Ann Neurol. 2002; 51(5): 645-648.

[33] Napoli, L., Bordoni, A., Zeviani, M., Hadjigeorgiou, G. M., Sciacco, M., Tiranti, V., Terentiou, A., Moggio, M., Papadimitriou, A., Scarlato, G., Comi, G. P. A novel missense adenine nucleotide translocator- 1 gene mutation in a greek adPEO family. Neurology. 2001; 57(12): 2295-2298.

[34] Siciliano, G., Tessa, A., Petrini, S., Mancuso, M., Bruno, C., Grieco, G. S., Malandrini, A., DeFlorio, L., Martini, B., Federico, A., Nappi, G., Santorelli, F. M., Murri, L. Autosomal dominant external ophthalmoplegia and bipolar affective disorder associated with a mutation in the ANT1 gene. Neuromuscul Disord. 2003; 13(2): 162-165.

[35] Galassi, G., Lamantea, E., Invernizzi, F., Tavani, F., Pisano, I., Ferrero, I., Palmieri, L., Zeviani, M. Additive effects of POLG1 and ANT1 mutations in a complex encephalomyopathy. Neuromuscul Disord. 2008; 18(6): 465-470.

[36] Horvath, R., Hudson, G., Ferrari, G., Fütterer, N., Ahola, S., Lamantea, E., Prokisch, H., Lochmüller, H., McFarland, R., Ramesh, V., Klopstock, T., Freisinger, P., Salvi, F., Mayr, J. A., Santer, R., Tesarova, M., Zeman, J., Udd, B., Taylor, R. W., Turnbull, D., Hanna, M., Fialho, D., Suomalainen, A., Zeviani, M., Chinnery, P. F. Phenotypic spectrum associated with mutations of the mitochondrial polymerase gamma gene. Brain. 2006; 129(7): 1674-1684.

[37] Chinnery, P. F. Mitochondrial Disorders Overview. In: Pagon, R. A., Adam, M. P., Ardinger, H. H., Bird, T. D., Dolan, C. R., Fong, C. T., Smith, R. J. H., Stephens, K., editors. GeneReviews(R). Seattle (WA): University of Washington, Seattle; 1993-2014. [updated 2014 Aug 14].

[38] Lax, N. Z., Whittaker, R. G., Hepplewhite, P. D., Reeve, A. K., Blakely, E. L., Jaros, E., Ince, P. G., Taylor, R. W., Fawcett, P. R., Turnbull, D. M. Sensory neuronopathy in patients harbouring recessive polymerase $\gamma$ mutations. Brain. 2012; 135(1): 62-71.

[39] Blok, M. J., van den Bosch, B. J., Jongen, E., Hendrickx, A., de Die-Smulders, C. E., Hoogendijk, J. E., Brusse, E., de Visser, M., Poll-The, B. T., Bierau, J., de Coo, I. F., Smeets, H. J. The unfolding clinical spectrum of $P O L G$ mutations. J Med Genet. 2009; 46(11): 776-785.

[40] Lamantea, E., Tiranti, V., Bordoni, A., Toscano, A., Bono, F., Servidei, S., Papadimitriou, A., Spelbrink, H., Silvestri, L., Casari, G., Comi, G. P., Zeviani, M. Mutations of mitochondrial DNA polymerase $\gamma \mathrm{A}$ are a frequent cause of autosomal dominant or recessive progressive external ophthalmoplegia. Ann Neurol. 2002; 52(2): 211-219.

[41] Luoma, P., Melberg, A., Rinne, J. O., Kaukonen, J. A., Nupponen, N. N., Chalmers, R. M., Oldfors, A., Rautakorpi, I., Peltonen, L., Majamaa, K., Somer, H., Suomalainen, A. Parkinsonism, premature menopause, and mitochondrial DNA polymerase gamma mutations: Clinical and molecular genetic study. Lancet. 2004; 364(9437): 875-882.

[42] Mancuso, M., Filosto, M., Oh, S. J., DiMauro S. A novel polymerase $\gamma$ mutation in a family with ophthalmoplegia, neuropathy, and parkinsonism. Arch Neurol. 2004; 61(11): 1777-1779.

[43] Hisama, F. M., Mancuso, M., Filosto, M., DiMauro, S. Progressive external ophthalmoplegia: A new family with tremor and peripheral neuropathy. Am J Med Genet A. 2005; 135(2): 217-219.

[44] Pagnamenta, A. T., Taanman, J. W., Wilson, C. J., Anderson, N. E., Marotta, R., Duncan, A. J., Bitner-Glindzicz, M., Taylor, R. W., Laskowski, A., Thorburn, D. R., Rahman, S. Dominant inheritance of premature ovarian failure associated with mutant mitochondrial DNA polymerase gamma. Hum Reprod. 2006; 21(10): 2467-2473.

[45] Hudson, G., Schaefer, A. M., Taylor, R. W., Tiangyou, W., Gibson, A., Venables, G., Griffiths, P., Burn, D. J., Turnbull, D. M., Chinnery, P. F. Mutation of the linker region of the polymerase gamma-1 (POLG1) gene associated with progressive external ophthalmoplegia and Parkinsonism. Arch Neurol. 2007; 64(4): 553-557.

[46] Invernizzi, F., Varanese, S., Thomas, A., Carrara, F., Onofrj, M., Zeviani M. Two novel POLG1 mutations in a patient with progressive external ophthalmoplegia, levodopa-responsive pseudo-orthostatic tremor and parkinsonism. Neuromuscul Disord. 2008; 18(6): 460-464.

[47] Johansen, K. K., Bindoff, L. A., Rydland, J., Aasly, J. O. Palatal tremor and facial dyskinesia in a patient with $P O L G 1$ mutation. Mov Disord. 2008; 23(11): 1624-1626.

[48] Remes, A. M., Hinttala, R., Kärppä, M., Soini, H., Takalo, R., Uusimaa, J., Majamaa, K. Parkinsonism associated with the homozygous W748S mutation in the POLG1 gene. Parkinsonism Relat Disord. 2008; 14(8): 652-654.

[49] Betts-Henderson, J., Jaros, E., Krishnan, K. J., Perry, R. H., Reeve, A. K., Schaefer, A. M., Taylor, R. W., Turnbull, D. M. Alpha-synuclein pathology and Parkinsonism associated with POLG1 mutations and multiple mitochondrial DNA deletions. Neuropathol Appl Neurobiol. 2009; 35(1): 120124.

[50] Synofzik, M., Asmus, F., Reimold, M., Schöls, L., Berg, D. Sustained dopaminergic response of Parkinsonism and depression in POLG-associated Parkinsonism. Mov Disord. 2010; 25(2): 243-245.

[51] Ferreira, M., Evangelista, T., Almeida, L. S., Martins, J., Macario, M. C., Martins, E., Moleirinho, A., Azevedo, L., Vilarinho, L., Santorelli, F. M. Relative frequency of known causes of multiple mtDNA deletions: Two novel POLG mutations. Neuromuscul Disord. 2011; 21(7): 483-488.

[52] Milone, M., Wang, J., Liewluck, T., Chen, L. C., Leavitt, J. A., Wong, L. J. Novel POLG splice site mutation and optic atrophy. Arch Neurol. 2011; 68(6): 806-811.

[53] Sato, K., Yabe, I., Yaguchi, H., Nakano, F., Kunieda, Y., Saitoh, S., Sasaki, H. Genetic analysis of two Japanese families with progressive external ophthalmoplegia and parkinsonism. J Neurol. 2011; 258(7): 1327-1332.

[54] Gurgel-Giannetti, J., Camargos, S. T., Cardoso, F., Hirano, M., Dimauro, S. POLG1 Arg953Cys mutation: Expanded phenotype and recessive inheritance in a Brazilian family. Muscle Nerve. 2012; 45(3): 453-454.

[55] Brandon, B. R., Diederich, N. J., Soni, M., Witte, K., Weinhold, M., Krause, M., Jackson, S. Autosomal dominant mutations in POLG and C10orf2: Association with late onset chronic progressive external ophthalmoplegia and Parkinsonism in two patients. J Neurol. 2013; 260(7): 1931-1933.

[56] Dolhun, R., Presant, E. M., Hedera, P. Novel polymerase gamma (POLG1) gene mutation in the linker domain associated with parkinsonism. BMC Neurol. 2013; 13: 92.

[57] Mukai, M., Sugaya, K., Yabe, I., Goto, Y., Yokochi, F., Miyamoto, K., Cai, H., Sasaki, H., Matsubara S. Neuromelanin MRI in a family with mitochondrial parkinsonism harboring a Y955C mutation in POLG1. Parkinsonism Relat Disord. 2013; 19(9): 821-824. 
[58] Van Goethem, G., Luoma, P., Rantamäki, M., Al Memar, A., Kaakkola, S., Hackman, P., Krahe, R., Löfgren, A., Martin, J. J., De Jonghe, P., Suomalainen, A., Udd, B., Van Broeckhoven, C. POLG mutations in neurodegenerative disorders with ataxia but no muscle involvement. Neurology. 2004; 63(7): 1251-1257.

[59] Komulainen, T., Hinttala, R., Kärppä, M., Pajunen, L., Finnilä, S., Tuominen, H., Rantala, H., Hassinen, I., Majamaa, K., Uusimaa, J. POLG1 p.R722H mutation associated with multiple mtDNA deletions and a neurological phenotype. BMC Neurol. 2010; 10: 29.

[60] Martikainen, M. H., Hinttala, R., Majamaa K. Novel POLG1 mutations in a patient with adult-onset progressive external ophthalmoplegia and encephalopathy. BMJ Case Rep. 2010; 2010.

[61] Roos, S., Macao, B., Fuste, J. M., Lindberg, C., Jemt, E., Holme, E., Moslemi, A. R., Oldfors A., Falkenberg, M. Subnormal levels of POL $\gamma$ A cause inefficient initiation of light-strand DNA synthesis and lead to mitochondrial DNA deletions and progressive external ophthalmoplegia. Hum Mol Genet. 2013; 22(12): 2411-2422.

[62] Mancuso, M., Filosto, M., Bellan, M., Liguori, R., Montagna, P., Baruzzi, A., DiMauro, S., Carelli, V. POLG mutations causing ophthalmoplegia, sensorimotor polyneuropathy, ataxia, and deafness. Neurology. 2004; 62(2): 316-318.

[63] Kollberg, G., Jansson, M., Pérez-Bercoff, A., Melberg, A., Lindberg, C., Holme, E., Moslemi, A. R., Oldfors A. Low frequency of mtDNA point mutations in patients with $\mathrm{PEO}$ associated with POLG1 mutations. Eur J Hum Genet. 2005; 13(4): 463-469.

[64] Schulte, C., Synofzik, M., Gasser, T., Schöls L. Ataxia with ophthalmoplegia or sensory neuropathy is frequently caused by POLG mutations. Neurology. 2009; 73(11): 898-900.

[65] Echaniz-Laguna, A., Chassagne, M., de Sèze, J., Mohr, M., Clerc-Renaud, P., Tranchant, C., Mousson de Camaret, B. POLG1 variations presenting as multiple sclerosis. Arch Neurol. 2010; 67(9): 1140-1143.

[66] Palin, E. J., Hakonen, A. H., Korpela, M., Paetau, A., Suomalainen, A. Mitochondrial recessive ataxia syndrome mimicking dominant spinocerebellar ataxia. J Neurol Sci. 2012; 315(1-2): 160-163.

[67] Engelsen, B. A., Tzoulis, C., Karlsen, B., Lillebø, A., Laegreid, L. M., Aasly, J., Zeviani, M., Bindoff, L. A. POLG1 mutations cause a syndromic epilepsy with occipital lobe predilection. Brain. 2008; 131(Pt 3): 818-828.

[68] Brinjikji, W., Swanson, J. W., Zabel, C., Dyck, P. J., Tracy, J. A., Gavrilova, R. H. Stroke and stroke-like symptoms in patients with mutations in the POLG1 gene. JIMD Reports. 2011; 1: 89-96.

[69] Neeve, V. C. M., Samuels, D. C., Bindoff, L. A., van den Bosch, B., Van Goethem, G., Smeets, H., Lombès, A., Jardel, C., Hirano, M., Dimauro, S., De Vries, M., Smeitink, J., Smits, B. W., de Coo, I. F., Saft, C., Klopstock, T., Keiling, B. C., Czermin, B., Abicht, A., Lochmüller, H., Hudson, G., Gorman, G. S., Turnbull, D. M., Taylor, R. W., HolinskiFeder, E., Chinnery, P. F., Horváth, R. What is influencing the phenotype of the common homozygous polymerase- $\gamma$ mutation p.Ala467Thr? Brain. 2012; 135(12): 3614-3626.

[70] Korhonen, J. A., Gaspari, M., Falkenberg, M. TWINKLE has $5^{\prime} \longrightarrow 3^{\prime}$ DNA helicase activity and is specifically stimulated by mitochondrial single-stranded DNA-binding protein. J Biol Chem. 2003; 278(49): 48627-48632.

[71] Echaniz-Laguna, A., Chanson, J. B., Wilhelm, J. M., Sellal, F., Mayençon, M., Mohr, M., Tranchant, C., Mousson de
Camaret, B. A novel variation in the Twinkle linker region causing late-onset dementia. Neurogenetics. 2010; 11(1): 21-25.

[72] Hudson, G., Deschauer, M., Busse, K., Zierz, S., Chinnery, P. F. Sensory ataxic neuropathy due to a novel C10Orf2 mutation with probable germline mosaicism. Neurology. 2005; 64(2): 371-373.

[73] Van Hove, J. L., Cunningham, V., Rice, C., Ringel, S. P., Zhang, Q., Chou, P. C., Truong, C. K., Wong, L. J. Finding twinkle in the eyes of a 71-year-old lady: A case report and review of the genotypic and phenotypic spectrum of TWINKLE-related dominant disease. Am J Med Genet A. 2009; 149a(5): 861-867.

[74] Virgilio, R., Ronchi, D., Hadjigeorgiou, G. M., Bordoni, A., Saladino, F., Moggio, M., Adobbati, L., Kafetsouli, D., Tsironi, E., Previtali, S., Papadimitriou, A., Bresolin, N., Comi, G. P. Novel Twinkle (PEO1) gene mutations in mendelian progressive external ophthalmoplegia. J Neurol. 2008; 255(9): 1384-1391.

[75] Martin-Negrier, M. L., Sole, G., Jardel, C., Vital, C., Ferrer, X., Vital, A. TWINKLE gene mutation: Report of a French family with an autosomal dominant progressive external ophthalmoplegia and literature review. Eur J Neurol. 2011; 18(3): 436-441.

[76] Lewis, S., Hutchison, W., Thyagarajan, D., Dahl, H. H. Clinical and molecular features of adPEO due to mutations in the Twinkle gene. J Neurol Sci. 2002; 201(1-2): 39-44.

[77] Hong, D., Bi, H., Yao, S., Wang, Z., Yuan, Y. Clinical phenotype of autosomal dominant progressive external ophthalmoplegia in a family with a novel mutation in the C10orf2 gene. Muscle Nerve. 2010; 41(1): 92-99.

[78] Bohlega, S., Van Goethem, G., Al Semari, A., Löfgren, A., Al Hamed, M., Van Broeckhoven, C., Kambouris, M. Novel Twinkle gene mutation in autosomal dominant progressive external ophthalmoplegia and multisystem failure. Neuromuscul Disord. 2009; 19(12): 845-848.

[79] Jeppesen, T. D., Schwartz, M., Colding-Jørgensen, E., Krag, T., Hauerslev, S., Vissing, J. Phenotype and clinical course in a family with a new de novo Twinkle gene mutation. Neuromuscul Disord. 2008; 18(4): 306-309.

[80] Ishihara, N., Fujita, Y., Oka, T., Mihara, K. Regulation of mitochondrial morphology through proteolytic cleavage of OPA1. EMBO J. 2006; 25(13): 2966-2977.

[81] Olichon, A., Emorine, L. J., Descoins, E., Pelloquin, L., Brichese, L., Gas, N., Guillou, E., Delettre, C., Valette, A., Hamel, C. P., Ducommun, B., Lenaers, G., Belenguer, P. The human dynamin-related protein OPA1 is anchored to the mitochondrial inner membrane facing the inter-membrane space. FEBS Lett. 2002; 523(1-3): 171-176.

[82] Yu-Wai-Man, P., Griffiths, P. G., Gorman, G. S., Lourenco, C. M., Wright, A. F., Auer-Grumbach, M., Toscano, A., Musumeci, O., Valentino, M. L., Caporali, L., Lamperti, C., Tallaksen, C. M., Duffey, P., Miller, J., Whittaker, R. G., Baker, M. R., Jackson, M. J., Clarke, M. P., Dhillon, B., Czermin, B., Stewart, J. D., Hudson, G., Reynier, P., Bonneau, D., Marques W Jr, Lenaers, G., McFarland, R., Taylor, R. W., Turnbull, D. M., Votruba, M., Zeviani, M., Carelli, V., Bindoff, L. A., Horvath, R., Amati-Bonneau, P., Chinnery, P. F. Multi-system neurological disease is common in patients with OPA1 mutations. Brain. 2010; 133(3): 771786.

[83] Ferraris, S., Clark, S., Garelli, E., Davidzon, G., Moore, S. A., Kardon, R. H., Bienstock, R. J., Longley, M. J., Mancuso, M., Gutiérrez Ríos, P., Hirano, M., Copeland, W. C., DiMauro, S. Progressive external ophthalmoplegia and 
vision and hearing loss in a patient with mutations in POLG2 and OPA1. Arch Neurol. 2008; 65(1): 125-131.

[84] Payne, M., Yang, Z., Katz, B. J., Warner, J. E., Weight, C. J., Zhao, Y., Pearson, E. D., Treft, R. L., Hillman, T., Kennedy, R. J., Meire, F. M., Zhang, K. Dominant optic atrophy, sensorineural hearing loss, ptosis, and ophthalmoplegia: A syndrome caused by a missense mutation in OPA1. Am J Ophthalmol. 2004; 138(5): 749-755.

[85] Meire, F., de Laey, J. J., de Bie, S., van Staey, M., Matton, M. T. Dominant optic nerve atrophy with progressive hearing loss and chronic progressive external ophthalmoplegia (CPEO). Ophthalmic Paediatr Genet. 1985; 5(1-2): 91-97.

[86] Treft, R. L., Sanborn, G. E., Carey, J., Swartz, M., Crisp, D., Wester, D. C., Creel D. Dominant optic atrophy, deafness, ptosis, ophthalmoplegia, dystaxia, and myopathy. A new syndrome. Ophthalmology. 1984; 91(8): 908-915.

[87] Chinnery, P. F., Johnson, M. A., Wardell, T. M., Singh-Kler, R., Hayes, C., Brown, D. T., Taylor, R. W., Bindoff, L. A., Turnbull, D. M. The epidemiology of pathogenic mitochondrial DNA mutations. Ann Neurol. 2000; 48(2): 188-193

[88] Humble, M. M., Young, M. J., Foley, J. F., Pandiri, A. R., Travlos, G. S., Copeland, W. C. Polg2 is essential for mammalian embryogenesis and is required for mtDNA maintenance. Hum Mol Genet. 2013; 22(5): 1017-1025.

[89] Craig, K., Young, M. J., Blakely, E. L., Longley, M. J., Turnbull, D. M., Copeland, W. C., Taylor, R. W. A p.R369G POLG2 mutation associated with adPEO and multiple mtDNA deletions causes decreased affinity between polymerase $\gamma$ subunits. Mitochondrion. 2012; 12(2): 313-319.

[90] Young, M. J., Longley, M. J., Li, F. Y., Kasiviswanathan, R., Wong, L. J., Copeland, W. C. Biochemical analysis of human POLG2 variants associated with mitochondrial disease. Hum Mol Genet. 2011; 20(15): 3052-3066.

[91] Longley, M. J., Clark, S., Yu Wai Man, C., Hudson, G., Durham, S. E., Taylor, R. W., Nightingale, S., Turnbull, D. M., Copeland, W. C., Chinnery, P. F. Mutant POLG2 disrupts DNA polymerase $\gamma$ subunits and causes progressive external ophthalmoplegia. Am J Hum Genet. 2006; 78(6): 1026-1034.

[92] Tanaka, H., Arakawa, H., Yamaguchi, T., Shiraishi, K., Fukuda, S., Matsui, K., Takei, Y., Nakamura, Y. A ribonucleotide reductase gene involved in a p53-dependent cell-cycle checkpoint for DNA damage. Nature. 2000; 404(6773): 42-49.

[93] Bourdon, A., Minai, L., Serre, V., Jais, J. P., Sarzi, E., Aubert, S., Chrétien, D., de Lonlay, P., Paquis-Flucklinger, V., Arakawa, H., Nakamura, Y., Munnich, A., Rötig, A. Mutation of $R R M 2 B$, encoding p53-controlled ribonucleotide reductase (p53R2), causes severe mitochondrial DNA depletion. Nat Genet. 2007; 39(6): 776-780.

[94] Fratter, C., Raman, P., Alston, C. L., Blakely, E. L., Craig, K., Smith, C., Evans, J., Seller, A., Czermin, B., Hanna, M. G., Poulton, J., Brierley, C., Staunton, T. G., Turnpenny, P. D., Schaefer, A. M., Chinnery, P. F., Horvath, R., Turnbull, D. M., Gorman, G. S., Taylor, R. W. RRM $2 B$ mutations are frequent in familial PEO with multiple mtDNA deletions. Neurology. 2011; 76(23): 2032-2034.

[95] Kato, M., Nakamura, M., Ichiba, M., Tomiyasu, A., Shimo, H., Higuchi, I., Ueno, S., Sano, A. Mitochondrial DNA deletion mutations in patients with neuropsychiatric symptoms. Neurosci Res. 2011; 69(4): 331-336.

[96] Alston, C. L., Schaefer, A. M., Raman, P., Solaroli, N., Krishnan, K. J., Blakely, E. L., He, L., Craig, K., Roberts, M., Vyas, A., Nixon, J., Horvath, R., Turnbull, D. M., Karlsson, A., Gorman, G. S., Taylor, R. W. Late-onset respiratory failure due to $T K 2$ mutations causing multiple mtDNA deletions. Neurology. 2013; 81(23): 2051-2053.

[97] Saada, A., Shaag, A., Mandel, H., Nevo, Y., Eriksson, S., Elpeleg, O. Mutant mitochondrial thymidine kinase in mitochondrial DNA depletion myopathy. Nat Genet. 2001;29(3): 342-344.

[98] Jüllig, M., Eriksson, S. Mitochondrial and submitochondrial localization of human deoxyguanosine kinase. Eur $\mathbf{J}$ Biochem. 2000; 267(17): 5466-5472.

[99] Dimmock, D. P., Zhang, Q., Dionisi-Vici, C., Carrozzo, R., Shieh, J., Tang, L. Y., Truong, C., Schmitt, E., SifryPlatt, M., Lucioli, S., Santorelli, F. M., Ficicioglu, C. H., Rodriguez, M., Wierenga, K., Enns, G. M., Longo, N., Lipson, M. H., Vallance, H., Craigen, W. J., Scaglia, F., Wong, L. J. Clinical and molecular features of mitochondrial DNA depletion due to mutations in deoxyguanosine kinase. Hum Mutat. 2008; 29(2): 330-331.

[100] Mandel, H., Szargel, R., Labay, V., Elpeleg, O., Saada, A., Shalata, A., Anbinder, Y., Berkowitz, D., Hartman, C., Barak, M., Eriksson, S., Cohen, N. The deoxyguanosine kinase gene is mutated in individuals with depleted hepatocerebral mitochondrial DNA. Nat Genet. 2001;29 (3): 337-341.

[101] Spinazzola, A., Viscomi, C., Fernandez-Vizarra, E., Carrara, F., D’Adamo, P., Calvo, S., Marsano, R. M., Donnini, C., Weiher, H., Strisciuglio, P., Parini, R., Sarzi, E., Chan, A., DiMauro, S., Rötig, A., Gasparini, P., Ferrero, I., Mootha, V. K., Tiranti, V., Zeviani, M. MPV17 encodes an inner mitochondrial membrane protein and is mutated in infantile hepatic mitochondrial DNA depletion. Nat Genet. 2006; 38(5): 570-575.

[102] Garone, C., Rubio, J. C., Calvo, S. E., Naini, A., Tanji, K., Dimauro, S., Mootha, V. K., Hirano, M. MPV17 mutations causing adult-onset multisystemic disorder with multiple mitochondrial DNA deletions. Arch Neurol. 2012; 69(12): 1648-1651.

[103] El-Hattab, A. W., Li, F. Y., Schmitt, E., Zhang, S., Craigen, W. J., Wong, L. J. MPV17-associated hepatocerebral mitochondrial DNA depletion syndrome: New patients and novel mutations. Mol Genet Metab. 2010; 99(3): 300-308.

[104] Kornblum, C., Nicholls, T. J., Haack, T. B., Schöler, S., Peeva, V., Danhauser, K., Hallmann, K., Zsurka, G., Rorbach, J., Iuso, A., Wieland, T., Sciacco, M., Ronchi, D., Comi, G. P., Moggio, M., Quinzii, C. M., DiMauro, S., Calvo, S. E., Mootha, V. K., Klopstock, T., Strom, T. M., Meitinger, T., Minczuk, M., Kunz, W. S., Prokisch, H. Loss-of-function mutations in MGME1 impair mtDNA replication and cause multisystemic mitochondrial disease. Nat Genet. 2013; 45(2): 214-219.

[105] Szczesny, R. J., Hejnowicz, M. S., Steczkiewicz, K., Muszewska, A., Borowski, L. S., Ginalski, K., Dziembowski, A. Identification of a novel human mitochondrial endo-/exonuclease Ddk1/c20orf72 necessary for maintenance of proper 7S DNA levels. Nucleic Acids Res. 2013; 41(5): 3144-3161.

[106] Duxin, J. P., Dao, B., Martinsson, P., Rajala, N., Guittat, L., Campbell, J. L., Spelbrink, J. N., Stewart, S. A. Human Dna2 is a nuclear and mitochondrial DNA maintenance protein. Mol Cell Biol. 2009; 29(15): 4274-4282.

[107] Ronchi, D., Di Fonzo, A., Lin, W., Bordoni, A., Liu, C., Fassone, E., Pagliarani, S., Rizzuti, M., Zheng, L., Filosto, M., Ferrò MT, Ranieri, M., Magri, F., Peverelli, L., Li, H., Yuan, Y. C., Corti, S., Sciacco, M., Moggio, M., Bresolin, N., Shen, B., Comi, G. P. Mutations in DNA2 link progres- 
sive myopathy to mitochondrial DNA instability. Am J Hum Genet. 2013; 92(2): 293-300.

[108] Casari, G., De Fusco, M., Ciarmatori, S., Zeviani, M., Mora, M., Fernandez, P., De Michele, G., Filla, A., Cocozza, S., Marconi, R., Dürr, A., Fontaine, B., Ballabio, A. Spastic paraplegia and OXPHOS impairment caused by mutations in paraplegin, a nuclear-encoded mitochondrial metalloprotease. Cell. 1998; 93(6): 973-983.

[109] Pfeffer, G., Gorman, G. S., Griffin, H., Kurzawa-Akanbi, M., Blakely, E. L., Wilson, I., Sitarz, K., Moore, D., Murphy, J. L., Alston, C. L., Pyle, A., Coxhead, J., Payne, B., Gorrie, G. H., Longman, C., Hadjivassiliou, M., McConville, J., Dick, D., Imam, I., Hilton, D., Norwood, F., Baker, M. R., Jaiser, S. R., Yu-Wai-Man, P., Farrell, M., McCarthy, A., Lynch, T., McFarland, R., Schaefer, A. M., Turnbull, D. M., Horvath, R., Taylor, R. W., Chinnery, P. F. Mutations in the SPG7 gene cause chronic progressive external ophthalmoplegia through disordered mitochondrial DNA maintenance. Brain. 2014; 137(5): 1323-1336.
[110] Wedding, I. M., Koht, J., Tran, G. T., Misceo, D., Selmer, K. K., Holmgren, A., Frengen, E., Bindoff, L., Tallaksen, C. M., Tzoulis, C. Spastic paraplegia type 7 is associated with multiple mitochondrial DNA deletions. PLoS One. 2014; 9(1): e86340.

[111] Banfi, S., Bassi, M. T., Andolfi, G., Marchitiello, A., Zanotta, S., Ballabio, A., Casari, G., Franco, B. Identification and characterization of $A F G 3 L 2$, a novel paraplegin-related gene. Genomics. 1999; 59(1): 51-58.

[112] Di Bella, D., Lazzaro, F., Brusco, A., Plumari, M., Battaglia, G., Pastore, A., et al. Mutations in the mitochondrial protease gene $A F G 3 L 2$ cause dominant hereditary ataxia SCA28. Nat Genet. 2010; 42(4): 313-321.

[113] Gorman, G. S., Pfeffer, G., Griffin, G., Blakely, E. L., Kurzawa-Akanbi, M., Gabriel, J., Sitarz, K., Roberts, M., Schoser, B., Pyle, A., Schaefer, A. M., McFarland, R., Turnbull, D. M., Horvath, R., Chinnery, P. F., Taylor, R. W. Clonal expansion of secondary mtDNA deletions associated with spinocerebellar ataxia type 28. JAMA Neurol. In press. 